\section{Assassins in Academia? New Zealand Academics as "Critic and Conscience of Society"}

\section{Todd Bridgman}

\section{Abstract}

This paper uses literature on the positioning of intellectuals in society to consider the enactment of the "critic and conscience" role within New Zealand universities. The critic and conscience of society is a statutory obligation for universities but is seen to be threatened by a combination of market forces and challenges to the status of knowledge. Drawing on the work of Laclau and Mouffe, the identity of the "critical and engaged expert" is constituted, which recognises the vital role that New Zealand academics can play as a force for democratic social change.

\section{Trade Me and the "Tall Poppy Assassin"}

"Let's hear it for the Trade Me genius" sang the New Zealand Herald in March 2006, following the sale of New Zealand's largest internet auction business to Australian-owned Fairfax for NZ\$700 million (Gaynor, 2006). The "genius" in the spotlight was Sam Morgan, who created the site as a 23-year-old in 1999 and sold it seven years later for a personal gain of NZ\$227 million. It all began, as the legend goes, with Morgan's need for a second-hand heater to warm his draughty Wellington flat. Frustrated by his experience of buying it using the internet, he created Trade Me.

Trade Me is heralded by the New Zealand media as a fairytale success story - a young Kiwi entrepreneur drops out of university and with the aid of a PC takes on the global might of eBay to create a personal fortune and inspire a whole generation of budding e-entrepreneurs along the way. The sale gained blanket coverage in New Zealand as journalists searched for every angle on Morgan and the secret of his success even his 93-year-old grandmother was asked for comment, having acquired something of a celebrity status at her Invercargill rest home (Levermore, 2006).
In the chorus of public approval that greeted the Trade Me sale, there was a lone voice of dissent. Craig Prichard, management lecturer at Massey University, issued a press release describing the sale as an “opportunity lost for New Zealand" (Prichard, 2006). Prichard acknowledged that Morgan and his fellow investors should realise a healthy return for their efforts, but argued that a concentration of wealth in such few hands was unreasonable, since Trade Me's value had been created by its customers' co-operative activity as well as their investment in internet-capable home computers. He suggested a number of options for dealing with the distribution of value from new economy firms such as Trade Me, including a preferential nominally priced block shareholding for staff and Trade Me traders as part of a public offering. Prichard also questioned whether it was really something to celebrate that yet another successful New Zealand enterprise had passed into Australian ownership, thereby leading us further down the road of economic dependence on our neighbour.

Despite the extent of the coverage on the Trade Me sale, most New Zealand media ignored Prichard's press release. Those who did not were scornful. The National Business Review described it as "an analysis that will leave most in management, let alone most economists, thunder struck" (Trade Me Sale Too Much Money for Too Few, 2006). Karl du Fresne, columnist for the Dominion Post, went further, labelling Prichard a "tall poppy assassin" who sits "safe and snug in his taxpayer-funded academic post" (2006, p. B4). Whereas Morgan had worked hard and made New Zealanders proud, Prichard "hasn't contributed a damn thing", he argued. Du Fresne was not much interested in engaging with the issues, but was puzzled by the background of this "previously unheard of management lecturer". Du Fresne found Prichard's university webpage and "stumbled into a morass of impenetrable academic mumbo-jumbo" littered with references to Michel Foucault and Karl Marx, who, he argued "have an alarming number of devotees in places of higher learning". 
I am not sure whether to be appalled that we pay academics to inculcate impressionable students with their madcap ideas, or grateful to Dr Prichard for coming forward and revealing himself.

It's useful to know what's going on in the universities (Du Fresne, 2006, p. B4).

This case presents a useful reference point for thinking about New Zealand academics' responsibilities as critic and conscience of society - responsibilities which are laid out in the Education Act 1989. While it is usual to stress the teaching and research roles of universities, their unique status also rests on their provision of a range of public good responsibilities which are crucial to a vibrant, informed and participatory democracy. These responsibilities, in turn, rely on the protection of academic freedom, defined in the Education Act as

the freedom of academic staff and students, within the law, to question and test received wisdom, to put forward new ideas and to state controversial or unpopular opinions (Education Act, 1989).

Aside from being a useful illustration of the critic and conscience role, Prichard's intervention over the Trade Me sale raises two other issues worthy of consideration: his location within a management school and his interest in social theory. The first prompts questioning about the positioning of management schools within the university and their relationship to established social science disciplines such as sociology. If the views of the National Business Review and the Dominion Post columnist are widely held, there is a presumption that management schools should be unquestioning supporters of the workings of the capitalist system, rather than critics of it.

For those working in New Zealand management schools, Prichard's comments should come as no surprise, since he is part of a strong and growing presence of critically inclined management academics. Critical management studies (CMS) is a branch of management theory critical of established social practices and institutional arrangements and challenges prevailing systems of domination. It has drawn together critical currents in the study of management that had been developing during the 1970s and 1980s and takes its name from Alvesson and
Willmott's edited collection published in 1992 (Alvesson \& Willmott, 1992). The movement developed initially in UK and Scandinavian business schools but has now spread to many parts of the globe including the US, where there is a CMS interest group at the Academy of Management.

The second issue to emerge is Prichard's interest in social theory, which was used as the weapon to bludgeon his credibility as a commentator on the Trade Me sale. To take critique of work and organisation in capitalist society seriously, one must look for theoretical lenses that inform a critique of capitalism, with Marxism and Foucauldian analysis being obvious starting points. The latter does, however, raise questions about the epistemological commitments of those who adopt the critic and conscience position.

The outline of the paper is as follows. In the following section, I suggest that the literature on the role of intellectuals in society provides a useful lens to rethink the enactment of the critic and conscience role within New Zealand universities. I first review a number of contributions heavily influenced by the Critical Theory of the Frankfurt School. These approaches focus on the role of science in legitimating academics' knowledge but are challenged by contributions which claim that intellectuals have lost their authority as bearers of objective, scientific knowledge. I then suggest that the work of Laclau and Mouffe can contribute to a theorisation of the relationship between intellectuals and society in two ways. First, it provides a theoretical framework for rethinking positions which are grounded in grand narratives such as positivist science and Marx's historical materialism. Second, it provides a horizon on which a new position for intellectuals can be constructed. This position, the critical and engaged expert, can fulfil an important role in Laclau and Mouffe's ideal of a radical and plural democracy. Finally, I return to the Trade Me case to consider the challenges and opportunities for the critic and conscience in New Zealand universities.

\section{Theorising the Critic and Conscience}

This section examines a number of conceptions of the intellectual. To a greater or lesser extent, Weber $(1949 ; 1989)$, Mills $(1951 ; 1958 ; 1959)$ and Mannheim (1991) appeal to a belief in the individual as a sovereign 
agent, a belief in reason, a belief in universal truths and values, and a belief in progressive emancipation through scientific knowledge. This constitutes the critical intellectual as a detached figure who stands above "the masses" and who claims superior access to objective, scientific knowledge. More recent contributors to the literature, such as Bauman (1987) and Foucault (1980), challenge this conception. I begin by examining Weber's position on value-freedom, which constructs a boundary between the spheres of science and politics.

For Weber (1989), specialisation is the only legitimate means of contributing to the life of the public sphere. Scientists contribute by providing factual, value-free knowledge that presents an alternative to prejudice and preconception and by recognising and respecting the limits of scientific knowledge with regard to its impotence on matters of moral choice. Weber argues the sphere of science is limited to answering "if", rather than "whether" questions, which belong in the sphere of politics. Academics, therefore, are urged by Weber to avoid engagement in politics. To do so risks confusing and compromising public confidence in science producing and disseminating unbiased, factual, value-free knowledge.

Like Weber, Mills believes in reason and emancipation through scientific knowledge. For Mills (1959), the academic is a political animal, since values guide the selection of problems for scientific study. However, in conducting scientific inquiry, these values should not determine the results or their moral or political implications. For Mills, the political role of the academic does not extend to an activist role, as this would indicate "a disbelief in the premise of social science and in the role of reason in human affairs" (p. 192). Completely objective social science is impossible, but this does not require the scientific paradigm to be abandoned.

The notion that the intellectual is somehow elevated or detached from the masses and is therefore able to study social life from the outside gives legitimacy to the position of the critical intellectual. This is achieved partly by an appeal to objectivity and the truthfulness of science, as articulated by Mills and Weber, but also by an assumption that intellectuals, unlike the masses, are able to transcend their immediate situation. For Mills, the political task of the scientist is to educate the masses about the structural causes of their personal situations because "by their own private experience they can only know a small portion of the social world" (1958, p.173).

This theme also appears in Mannheim's conception of the "freely floating intellectual". Like Mills, Mannheim (1991) asserts there is no possibility of discovering a universal truth, since there are multiple competing worldviews on the political landscape. However, it is possible to produce a synthesis of these worldviews and that task belongs to a relatively classless stratum, the "socially unattached intelligentsia" (Mannheim, 1991, p.137, emphasis in original). Mannheim asserts that the intelligentsia share a common heritage of education, which, unlike those without education, enables them to keep an open mind rather than blindly accepting the ideology of a particular group. Education, therefore, is the source of autonomy and independence, enabling intellectuals to take a "broader point of view" to capture the "whole of the social and political structure" (1991, p.162). This external view allows intellectuals to reflect critically on what is widely taken for granted. Intellectuals can attach themselves to classes in situations where members of those classes are unable to theorise their own position, but this affiliation does not imply subservience.

Weber, Mills and Mannheim formulate different conceptions of the social role of intellectuals, but they share a belief that the critical intellectual is a sovereign agent who is guided by reason, the search for "truth" and the possibility of emancipation through scientific discovery. Other contributors to the literature, such as Bauman and Foucault have challenged these positions and it is to them that I now turn.

For Bauman (1987), intellectuals (or more specifically, public intellectuals) are a product of the Enlightenment, appealing to reason, standing outside partisan politics and rising above one's specialisation to address issues of broader public concern. Bauman argues there has been a shift from modern intellectuals as legislators of universal values to postmodern intellectuals as interpreters of social meanings. The modern strategy of intellectual work is the "legislator" role, which "consists of making authoritative statements which arbitrate in 
controversies of opinions and selects those opinions which, having been selected, become correct and binding" (Bauman, 1987, p.4). For legislators, the authority of knowledge is grounded in the use of procedural rules, such as the scientific method, which assures the attainment of truth and moral judgement. Since their knowledge is universally valid, legislators have the right and duty to validate beliefs which are held in various sections of society. Bauman criticizes Mannheim's concept of the freely floating intellectual for trying to revive the idea of intellectuals as legislators. Mannheim gives the intellectuals the mission of adjudicating between ideologies, to reveal them as partial and prejudiced world-views and to disclose their lack of universal foundation. The intellectual therefore, assumes a privileged position of independence above all particularised social locations and stands above the political world as analyst and critic (Bauman, 1987).

The irony, suggests Bauman, is that the concept of intellectuals was constituted at a time when the unity of reason was already breaking down. According to Bauman, modernist discourses assume that there is nothing beyond modernity - that it is progressive, inevitable and the highest point of development. For Bauman, postmodernism has exposed this myth, viewing modernity as "an enclosed object, an essentially complete product, an episode of history, with an end as much as a beginning" (p. 117). The objectification of modernity questions the authority claims upon which it is grounded, creating a crisis of confidence in the intellectual community. The belief in universal truth and judgement has been replaced by recognition that the validity of the judgement depends on the site from where it has been made and the authority ascribed to that site. Bauman argues that since the authority of intellectuals in no longer taken for granted, intellectuals must adopt a new, postmodern role of interpreters, which "consists of translating statements, made within one communally based tradition, so that they can be understood within the system of knowledge based on another tradition" (Bauman, 1987, p.5). In the interpreter role, legislative ambitions are abandoned, given the plurality of world-views. In a world where consensus on values is unlikely, the interpreter becomes a mediator of communication between communities, a specialist in the "art of civilized conversation" (p.143) whose aim is conveying understanding, rather than making judgements. Bauman's position has similarities with Habermas (1991), whose model of communicative action is also based on mutual understanding and shared knowledge. However, while Bauman believes that consensus is unlikely, Habermas has faith in reason and the possibility of a rational consensus.

Foucault's (1980) target of critique is the "universal intellectual", which closely resembles Bauman's legislator role. Foucault opposes Left intellectuals (such as Jean-Paul Sartre) who purport to represent universal values and who purport to speak on behalf of others, such as the proletariat. The universal intellectuals are represented spatially as being outside, a positioning which gains legitimacy from a sense of detachment, which supposedly permits an objectivity and a sense of being able to see things in their true form. Foucault rejects this positioning on both ontological and political grounds. Ontologically, he rejects the idea that academics can be outside the "truth", instead locating them within a regime of truth through their production, control and dissemination of knowledge. For Foucault, truth is not outside power. Politically, he argues that the universal intellectual is not connected in practice with political struggles and therefore has little influence on these struggles. In "Truth and Power" Foucault claims the universal intellectual has been replaced by the "specific intellectual", who operates "within specific sectors, at the precise points where their own conditions of life or work situate them (housing, the hospital, the asylum, the laboratory, the university, family and sexual relations)" (1980, p.126).

Foucault is concerned with politics, however it is a different form of politics from those influenced by the Critical Theory of the Frankfurt School. Foucault's specific intellectuals necessarily occupy a specific position and engage with real, material, everyday struggles. He believes they are a potentially revolutionary force, not because they represent the truth of the oppressed, but because they can problematise systems of power/knowledge domination from their own location (Foucault, 1980).

The issue of representation is problematic for both Bauman and Foucault and raises doubts about the viability of academics engaging in critical public work. For the legislator or universal intellectual, their 
primary role is representation, justified on the grounds that intellectuals have an external perspective that the masses do not, or that their job is to formulate the ideology for the class with which they choose to affiliate. In contrast, Bauman's interpreter merely conveys understanding and facilitates communication, while Foucault is hostile towards any role for intellectuals in representing the masses, seeing that as part of the problem, rather than the solution (Radhakrishnan, 1990). This concern, together with claims that academics, as intellectuals, can no longer credibly stand as the bearer of universal values, questions the legitimacy of academics' critical engagement with the public. If academics problematise the nature of concepts such as justice, truth and human rights, how can they engage meaningfully in public debate?

\section{Rethinking the Critic and Conscience}

The discourse theory of Laclau and Mouffe is an emerging analytical framework within organisation studies, offering an alternative to established approaches such as Foucauldian analysis and critical discourse analysis (Bridgman \& Willmott, 2006; Willmott, 2005). Laclau and Mouffe's theorising has generated considerable interest within New Zealand, following the establishment of a month-long summer school programme at Victoria University in 2003. Courses are taken by leading international discourse theorists and attract faculty and postgraduate students from across the disciplinary spectrum. Of relevance to this paper is not Laclau and Mouffe's theory of discourse per se, but their articulation of a political space within which intellectuals can work.

Laclau and Mouffe draw upon structuralist, poststructuralist and psychoanalytic traditions to elaborate an approach that highlights the contingency of identity, thereby questioning the Marxist assumption that identity is determined by the part played out in the relations of production. Laclau and Mouffe (1985), for example, argue that classical Marxism's privileging of a class identity cannot account for the emergence of new social movements, which do not appear to be organised around class-consciousness. This critique can also be deployed to rethink conceptions of the social role of intellectuals that privilege a structural location within the relations of production. Gramsci, for instance, believed that every class "creates together with itself, organically, one or more strata of intellectuals which give it homogeneity and an awareness of its own function" (1971, p.5). The role of the intellectual is to secure hegemony for the dominant class, or any class that seeks to replace it. From the perspective of Laclau and Mouffe, Gramsci goes beyond the concept of class in developing a theory of hegemony, yet retains a foundationalist position by assuming that class remains a single unifying principle.

Mannheim is another who develops his position on intellectuals on a class foundation. Despite positing that intellectuals are a "relatively classless stratum" (1991, p.137) and therefore freely-floating, Mannheim observes that in history intellectuals have always attached themselves to one class or another, since people from these classes are not capable of theorising their own position. Konrad and Szelenyi (1979) and Gouldner (1979) also refer to a structural location, arguing that intellectuals have become a new class in themselves, pretending to carry out the historical mission of the working class, but instead establishing their own class domination over the working class. This is not to suggest that these theorists conceive of the role of intellectuals as being determined by their part in the relations of production. However, Laclau and Mouffe provide a way of thinking about the role of intellectuals that does not rely on the concept of class, by seeing the identity of the intellectual as the product of a hegemonic struggle between competing political projects.

Laclau and Mouffe also provide a means for interrogating the idea of the sovereign individual with preconstituted interests, which is evident in Weber's conception of the value-free expert. For Weber, the vocational mission of the scientist is limited to providing value-free technical expertise that enables people to make informed choices between alternative courses of action. Scientists are constituted as value-free experts, heroically pursuing a project of progressive knowledge production within a specialised field of inquiry, totally unresponsive to questions of values, or the commercial exploitation of their work. Weber sees agents as motivated by preconstituted interests, such as vocation. From the perspective of Laclau and Mouffe, the identity 
of the value-free specialist is seen as a contingent identity thrown up by a (positivist) project of progressive knowledge production (Bridgman \& Willmott, 2007). Does this mean however, that we can no longer advocate any positive role for intellectuals? Can Laclau and Mouffe's work form the basis of a progressive politics and if so, what is the role of intellectuals? In the remainder of this section I suggest that the insights of Laclau and Mouffe do not inevitably lead to political nihilism, by using the concept of radical and plural democracy to articulate a positive role for the intellectual.

Laclau and Mouffe are notable for articulating a new political direction for Left politics. Far from neglecting the difficult political questions, the impetus for Laclau and Mouffe was very much political - a desire to reformulate the Left project in a way that connects the struggle of the working class and the struggle of new social movements. The concept of a radical and plural democracy is the nodal point of their political theory and it can be used to construct a positive role for academics as engaged critics who extend the boundaries of public debate.

Laclau and Mouffe's project of a radical and plural democracy attempts to defend the political content of the Enlightenment, such as justice, equality and freedom, whilst abandoning its epistemological foundations of the sovereign individual and reason. Mouffe argues that while democracy is the distinctive feature of modernity, postmodern thinking has recognised "the impossibility of any foundation or final legitimation that is constitutive of the very advent of the democratic form of society and thus of modernity itself" (Mouffe, 1998, p.34). Despite rejecting the foundations of modernity, Laclau and Mouffe believe this does not lead to political nihilism. Universality is an impossibility - an empty place that competing political struggles attempt to fill with meaning. In this context, the Enlightenment is read as one hegemonic articulation that competes to represent the universality of the social order, a horizon that is constructed through political argument. Far from ending up in a "relativist gloom" (Geras, 1987, p.67), this asserts the importance of continued political struggle, to defend positions from competing articulations that seek to transform and undermine them.
A radical and plural democracy is, therefore, the site of struggle between competing hegemonic articulations, where each seeks to fill the empty place of the universal, yet ultimately fails to do so. Laclau and Mouffe's position is distinct from Habermas (1987), for whom communicative action is the basis of a model of the public sphere which is oriented towards mutual understanding and common action. Both Laclau and Mouffe and Habermas highlight the importance of taking multiple perspectives into account, but Laclau and Mouffe preclude the possibility of any rational consensus, as envisaged by Habermas, on the basis that in a rational consensus relations of power will have disappeared - an impossibility since relations of power are constitutive of the social. Mouffe (1998) argues that Habermas, by theorising the possibility of a rational consensus, inadvertently undermines the democratic pluralist process. In Western democratic societies, this is leading to a consensus model where political parties from the Left and Right are congregating in the centre of the political spectrum, which reduces the opportunity for people to identify with alternative positions and contributes to disinterest and passivity in politics. For Laclau and Mouffe, a vibrant democracy is characterised by a "real struggle against different positions" (1999, p.25).

The project of radical and plural democracy is therefore about multiplicity, conflict and participation. I suggest that we can use it to rethink the role of intellectuals in society, and more specifically, to rethink the role of New Zealand academics as critic and conscience. In a radical and plural democracy, the function of intellectuals is to articulate positions that challenge received wisdom and by doing so widen the scope of democratic debate. This process of articulation takes place through active engagement with social movements engaged in political struggle. Intellectuals in a radical and plural democracy appeal to values, but recognise these values as social constructs that are the result of political struggle, rather than essential entities whose form and meaning is fixed for all time.

It is tempting to construct a label for this conception of the intellectual, since almost everyone engaged in the debate about the role of intellectuals does so. While it can be argued that faculty perform the 
function of intellectuals, the signifier intellectual has little resonance with my academic colleagues. The term I prefer is "critical and engaged expert" (Bridgman, forthcoming). "Critical" implies that academics recognise as one of their primary roles the articulation of positions that challenge conventional ideas and received wisdom. Along with Mills, I see value in academics being unconstructive, in that it assists in creating an environment where prevailing ideas and attitudes can be scrutinised. In this way, being unconstructive, through offering critique, becomes constructive for a healthy democracy. "Engaged" implies that academics interact not only with students and other academics, but with audiences outside the university, such as businesses, government, think-tanks, political parties and journalists.

Consistent with Foucault, I reject the notion of the universal intellectual who is spatially represented as outside, which supposedly permits objectivity and an ability to see things in their true form. However, I would not go as far as Foucault in suggesting that academics have no privileged position from which to participate in political life. I would also not go as far as Bauman, whose interpreter forgoes all legislative ambitions and becomes a mediator of communication. The critical and engaged expert is privileged in the sense of having the time and other resources to contemplate and scrutinise social life that others outside the university do not possess. However, it does not follow that the knowledge they produce is objective and value-free. The critical and engaged expert acknowledges that they speak from a particular value orientation and they do not claim to speak the "truth". Their role is a political one - to secure hegemony for values such as justice, freedom and equality that construct a horizon for social transformation.

\section{Being the Critic and Conscience in New Zealand: Issues, challenges and} opportunities

What then, of the challenges and opportunities for the performance of this activity in New Zealand? The prospects for the New Zealand critic and conscience has attracted considerable interest in recent years, following a symposium on the public intellectual held at University of Auckland in 2003 and the publication of a series of interviews with New
Zealand public intellectuals (Simmons, 2007). The term public intellectuals rests uncomfortably with me, as it does with many of those featuring in the book, largely because of what is regarded as the antiintellectualism of New Zealanders.

Horrocks (2007) identifies numerous sources of New Zealand's antiintellectualism, starting with our small population, isolation and ruralism. Prevailing colonial attitudes are blamed for the suppression of Maori intellectual activity while puritanism and egalitarianism have, argued Horrocks, created a fear of difference. Another significant factor is New Zealand's pioneer culture, which privileges Kiwi ingenuity and undervalues academic achievement (Horrocks, 2007; Roberts, 1999). Turner (2007, p.85) sums it up nicely when he states that "just talking about public intellectuals makes you.... a wanker rather than a wellrounded bloke".

In addition to the challenge of confronting anti-intellectualism, the New Zealand critic and conscience is seen to be threatened by an "enterprise culture" (Du Gay, 1996) within our universities. Through an application of a revolutionary new-right agenda state intervention in society has been reduced in many areas and redefined in others, involving processes of corporatisation, privatisation, commercialisation and marketisation. The university has not been immune to this transformation, with managerialism seemingly taking an ever stronger hold (Larner \& Le Heron, 2005). This shapes not just its teaching and research functions, but also prompts concern about academic freedom and the future of the critic and conscience in this environment (Roberts, 1999; Savage, 2000). With New Zealand universities increasingly reliant on external sponsors and concerned with their brand image in a competitive tertiary sector, the fear is that academics will hesitate to go public with controversial positions that might raise the ire of university management.

This pessimistic assessment was made before the introduction of the Performance Based Research Fund (PBRF), which encourages New Zealand academics to write for other academics rather than the public, with career advancement largely based on publication in journals that are read only by fellow academics. In writing about the United States, 
Jacoby (1987) identifies this professionalisation of academic labour as a key contributor to the decline of the public intellectual. Jacoby believes that "for many professors in many universities academic freedom meant nothing more than the freedom to be academic" (p. 118). It remains to be seen what the effect of the PBRF on critic and conscience activity in New Zealand will be.

It is worth noting that Simmons' collection of New Zealand public intellectuals includes no representatives from either management studies or sociology (2007). It has two from history and one each from economics, religious studies, law, public policy and Maori studies, as well as a journalist, protest activist and a poet. Perhaps we should not be surprised at this. Turner (2006) attributes the "modest achievements of British sociology" (p. 175) and the dearth of British sociologist public intellectuals in part to anti-intellectualism and individualism, both of which are influential in New Zealand. The phenomenon of management school academics as critic and conscience appears an even greater contradiction, given the primacy of concepts such as the knowledge economy and the role of management schools in it.

This makes the intervention by Prichard in the Trade Me debate interesting and unusual. It is also a useful illustration of the position of critical and engaged expert. Prichard is certainly critical, since he articulated a position that opposed the tide of positive feelings surrounding the Trade Me sale. Sadly, his challenge to the mainstream media's construction of the story did not receive adequate consideration, probably because it was considered to be outside the realm of acceptable political debate in New Zealand at this time. Instead of generating a lively discussion, all that resulted was a personal attack. Prichard was definitely engaged, taking it on himself to produce a press release. Finally, it is reasonable to conclude that Prichard was an expert in this area, given his academic background and positioning within a school of management. Crucially however, this notion of expertise is not wedded to any appeal to impartiality, objectivity or a claim to be speaking the "truth". It might have been informed by a Marxist critique of capitalist political economy, but the point is that such a foundation should not be viewed as essential to acting as the critic and conscience. Prichard's intervention into the Trade Me debate was most definitely a political intervention based on a particular set of values and no apology need be made for this. Those who lauded the Trade Me sale also did so from a particular value position, but since these values are hegemonic within mainstream media discourse, they largely escape critical scrutiny. Prichard's actions were exactly the kind of critic and conscience work we should be engaging in.

Despite the feelings of pessimism that linger around the prospects for the New Zealand academic as critic and conscience, there is some cause for optimism. There is some hope of critic and conscience activity being valued as part of service and/or a contribution to the research environment in the PBRF. It is pleasing that a search of New Zealand university websites finds numerous references to the critic and conscience obligations of these institutions. University of Otago, for instance, actively promotes Dare to be Wise, a collection of columns in major daily newspapers written by its academics on issues of public concern. Initiatives such as this are useful ways of promoting the institution and they also satisfy demands from external stakeholders for relevance (Bridgman, forthcoming). Paradoxically then, there are also opportunities for the preservation of the critic and conscience in a competitive New Zealand tertiary sector, even if undertaken for partly or wholly instrumental reasons.

Finally, it is important to recognise the potential costs of sticking one's head above the parapet. Jane Kelsey, a staunch supporter of the critic and conscience position and herself an outspoken critic on a range of social and political issues, believes the role comes with "significant emotional, psychological risk, because it can get quite nasty and vicious" (Kelsey, 2007, p.147). Prichard's foray into the Trade Me issue took considerable courage and it would have been far easier to confine his views to his CMS colleagues, from whom he would most likely have received a sympathetic hearing. He, and others like him, deserve our active support. 


\section{Conclusion}

Literature on the social role of intellectuals provides valuable insights into how a critical public role for New Zealand academics can be theorised. In reviewing seminal contributions from Weber to Foucault, I have identified constructions of intellectuals which draw on discourses of reason, science and universality, as well as conceptions which problematise these discourses. In the former, intellectuals stand apart from and above the masses on the basis of their superior knowledge. Alternative conceptions reject this identity in favour of a positioning of intellectual activity within a specific and local site. Taken to its extreme, these positions denounce any privileged role for academics.

Consistent with the philosophical premises of Laclau and Mouffe, the critical and engaged expert can be located somewhere between the positions of Weber and Mills and those of Bauman and Foucault. Bauman and Foucault's ideas are useful for rethinking the social role of intellectuals, but they go too far by abandoning the notion of a politicised role for university faculty connected to a coherent political project. Faculty can appeal to concepts such as justice, fairness and rights, but in the knowledge that these concepts are the product of political struggle, rather than essential, natural entities whose meaning is secure for all time. They can continue to legislate but without making claims to universality. The concept of radical and plural democracy is a horizon that can guide political activity by academics without an appeal to foundations. Far from breeding nihilism and anti-politics, the insights of Laclau and Mouffe demonstrate the primacy of politics and the vital role that New Zealand academics can play as a force for social change.

\section{References}

Alvesson, M \& Willmott, H. (1992). Critical management studies. London: Sage.

Bauman, Z. (1987). Legislators and interpreters: On modernity, post-modernity and intellectuals. New York: Cornell University Press.

Bridgman, T. (forthcoming). Reconstituting relevance: Exploring possibilities for management educators' critical engagement with the public. Management Learning.

Bridgman, T\& Willmott, H. (2006). Institutions and technology: Frameworks for understanding organizational change- the case of a major IT outsourcing contract, Journal of Applied Behavioral Science, 42(1), 110-126.
Bridgman, T. \& Willmott, H. (2007). Academics in the 'knowledgeeconomy': Fromexpert to intellectual? In C. Burtscher, A. Harding, S. Laske, \& A. Scott (Eds.): Bright satanic mills: Universities, regional development and the knowledgeeconomy (pp. 149-162). Aldershot, Hants: Ashgate.

Du Fresne, K. (21 March, 2006). An assassinin academia. Dominion Post, B4.

Du Gay, P. (1996). Consumption and identity at work. London: Sage.

Education Act (1989). Wellington: Government Printer.

Foucault, M. (1980). Truth and Power. In C. Gordon (Ed.):Power/knowledge: Selected interviews and other writings 1972-77 (pp.109-133.). New York: Pantheon.

Gaynor, B. (2006, March11). Let's hear it for the Trade Me genius. New Zealand Herald, Retrieved 10 November, 2006 from Newztext database.

Geras, N. (1987). Post-marxism? New Left Review, 163(May-June), 40-82.

Gouldner, A. (1979). The future of intellectuals and the rise of the new class. London: Macmillan.

Gramsci, A. (1971). Selection from the prison notebooks of Antonio Gramsci. London: Lawrence and Wishart.

Habermas, J. (1987). The theory of communicative action. Cambridge: Polity.

Habermas, J. (1991). Communication and theevolution of society. Cambridge: Polity

Horrocks, R. (2007). A short history of 'the New Zealand intellectual'. InL. Simmons (Ed.): Speaking Truth to Power (pp. 25-67). Auckland: Auckland University Press,

Jacoby, R. (1987). The last intellectuals: American culture in the age of academe. New York: Basic Books.

Kelsey, J. (2007). Jane Kelsey. In L. Simmons (Ed.): Speaking Truth to Power (pp. 141-162). Auckland: Auckland University Press,

Konrad, G. \& Szelenyi, I. (1979). The intellectuals on the road to class power. Brighton: Harvester

Laclau, E. \& Mouffe, C. (1985). Hegemony and socialist strategy: Towards a radical democratic politics. London: Verso.

Laclau, E. \& Mouffe, C. (1999). An interview with Chantal Mouffe and Ernesto Laclau. [Accessed February 25, 2007].http://www.english.ilstu.edu/strickland/495/laclau2.html.

Larner, W. \& LeHeron, R. (2005). Neo-liberalizing spaces and subjectivities: Reinventing New Zealand universities. Organization, 12(6), 843-862.

Levermore, E. (2006, 8 March). Sam's gran proud of his online success. Southland Times. Retrieved 10 November 2006 from Newztext database.

Mannheim, K. (1991). Ideology and utopia. London: Routledge.

Mills, C. W. (1951). White collar: The American middle classes. New York: Oxford University Press. Mills, C. W. (1958). The causes of World War Three. London: Secker \& Warburg.

Mills, C. W. (1959). The sociological imagination. New York: Oxford University Press.

Mouffe, C. (1998). Radical democracy: Modernor postmodern? In Ross, A. (Ed.): Universal abandon? The politics of postmodernism (pp. 31-45). Edinburgh: Edinburgh University Press.

Prichard, C. (2006). Sale of Trade Me a Lost Opportunity. Massey University Press Release http:// masseynews.massey.ac.nz/2006/Press_Releases/03-15-05.html 
Radhakrishnan, R. (1990). Toward an effective intellectual: Foucault or Gramsci? In Robbins, B. (Eds.): Intellectuals: Aesthetics, politics, academics (pp. 57-99). Minneapolis: University of Minnesota Press.

Roberts, P. (1999). The future of the university: Reflections from New Zealand. International Review of Education, 45(1), 65-85.

Savage, D. C. (2000). Academic freedom and institutional autonomy in New Zealand universities. In R. Crozier (Ed.), Troubled Times: Academic Freedom in New Zealand. Palmerston North: Dunmore Press.

Simmons, L. (Ed.). (2007). Speaking Truth to Power. Auckland: Auckland University Press.

Trade Me Sale Too MuchMoney for Too Few, Says Massey Professor. (2006, March 15). National Business Review, Retrieved November 10, 2006 from

ttp://www.nbr.co.nz/home/column_article.asp?id=14652\&cid=4\&cname=

Turner, B. (2006). British sociology and public intellectuals: consumer society and imperial decline. British Journal of Sociology, 57(2), 169-188.

Turner, S. (2007). The public intellectual is a dog. In L. Simmons (Ed.), Speaking Truth to Power (pp. 85101). Auckland: Auckland University Press.

Weber, M. (1949). The meaning of "ethical neutrality" in sociology and economics. In Shils, E and Finch, H. (Eds.): Max Weber on the methodology of the social sciences (pp.1-47.). Illinois: Free Press.

Weber, M. (1989). Science as a vocation. In Lassman, P. and Velody, I. (Eds.): Max Weber's 'scienceas a vocation' (pp.3-31). London: Unwin Hyman.

Willmott, H. (2005). Theorizing contemporary control: Some post-structuralist responses to some critical realist questions, Organization, 12(5), 747-780.

Todd Bridgman is a lecturer inorganisational behaviour at Victoria University of Wellington. Hewas previously a postdoctoral fellow at the Judge Business School, University of Cambridge, where he completed his PhD. His doctoral thesis, whichwasjudged best doctoral thesis in Critical Management Studies at the Academy of Management 2005, investigates the commercialisation of the academic's public role. He is currently co-editing a Handbook of Critical Management Studies (Oxford University Press).

\section{Young, Working, Studying: Labour Market Patterns and Education Sector Expansion}

Catherine Casey and Kate Williamson

\section{Abstract}

Simultaneous participation in post-compulsory education and labour markets has emerged as a pattern consequent of both the liberalisation of employment relations and the expansion of post-compulsory education in the OECD countries over the past two decades. This article, based on an empirical study conducted in New Zealand in 2005 and 2006, discusses students combining study and employment. The article argues that although students seek to maximise the benefits associated with their employment, employers ultimately gain more in the short and long-term from a significant pool of low-cost, low-investment, highly flexible labour.

\section{Introduction}

Young people are engaging in post-secondary education in unprecedented numbers, and many of these young people are simultaneously active participants in the world of work. The development of a pattern of close interaction between post-compulsory education and labour market participation is occurring in the context of work practices that are emerging as New Zealand pursues official policies on developing a knowledge-based economy in the wake of the neo-liberal orthodoxies of the 1980s and 1990s. This article observes and analyses some of the young student-workers who, as a cohort, are generally expecting to participate in knowledge-intensive technical and professional work in a burgeoning technologically mediated knowledgebased economy and who are participating as core labour force in a range of low-skilled and contingent service sector jobs.

Much has been written about the changing patterns of employment relations under the liberalisation of the labour market since the 1980s, and this current study adds a further discussion of continuing effects 